\title{
Bacteroides clarus sp. nov., Bacteroides fluxus sp. nov. and Bacteroides oleiciplenus sp. nov., isolated from human faeces
}

\author{
Yohei Watanabe, Fumiko Nagai, Masami Morotomi, Hiroshi Sakon \\ and Ryuichiro Tanaka
}

Correspondence

Yohei Watanabe

yohei-watanabe@yakult.co.jp

\author{
Yakult Central Institute for Microbiological Research, 1796 Yaho, Kunitachi, 186-8650 Tokyo, \\ Japan
}

\begin{abstract}
Three Gram-stain-negative, obligately anaerobic, non-spore-forming, rod-shaped bacteria (strains YIT $12056^{\top}$, YIT $12057^{\top}$ and YIT $12058^{\top}$ ) were isolated from human faeces. These strains were characterized by phylogenetic analyses based on 16S rRNA gene sequence and phenotypic tests. 16S rRNA gene sequence analyses revealed that strains YIT $12056^{\top}$, YIT $12057^{\top}$ and YIT $12058^{\top}$ were most closely related to the type strains of Bacteroides gallinarum, Bacteroides uniformis and Bacteroides intestinalis with approximate similarity values of $96.6,95.0$ and $96.7 \%$, respectively. The DNA G $+C$ contents of the novel strains were 45.3 (YIT 12056 ${ }^{\top}$ ), 45.2 (YIT $\left.12057^{\top}\right)$ and $43.6 \mathrm{~mol} \%\left(\mathrm{YIT} 12058^{\mathrm{T}}\right)$ and the major respiratory quinones of all three isolates were menaquinones $\mathrm{MK}-10$ and $\mathrm{MK}-11$. These properties were typical for members of the genus Bacteroides. The results of the other phenotypic analyses also supported the affiliation of these strains to the genus Bacteroides. The 16S rRNA gene sequence analysis, analysis of the major cellular fatty acids and other biochemical tests enabled the genotypic and phenotypic differentiation of the three new strains. Based on these data, three novel species, Bacteroides clarus sp. nov., Bacteroides fluxus sp. nov. and Bacteroides oleiciplenus sp. nov. are proposed. The type strains of $B$. clarus, $B$. fluxus and $B$. oleiciplenus are YIT $12056^{\top}\left(=\mathrm{JCM} 16067^{\top}=\mathrm{DSM}\right.$ $\left.22519^{\top}\right)$, YIT $12057^{\top}\left(=\mathrm{JCM} 16101^{\top}=\mathrm{DSM} 22534^{\top}\right)$ and YIT $12058^{\top}\left(=\mathrm{JCM} 16102^{\top}=\mathrm{DSM}\right.$ $\left.22535^{\top}\right)$, respectively.
\end{abstract}

The human gastrointestinal (GI) tract harbours a diverse and abundant microbiota and recent advances in cultureindependent molecular techniques, such as 16S rRNA gene sequencing or metagenome shotgun sequencing, have contributed to increased understanding of this bacterial community (Eckburg et al., 2005; Kurokawa et al., 2007). Most of these organisms are members of the phyla Bacteroidetes and Firmicutes (Eckburg et al., 2005; Hayashi et al., 2002; Wang et al., 2003). Among the phylum Bacteroidetes, species belonging to the genus Bacteroides in the family Bacteroidaceae, such as Bacteroides vulgatus, Bacteroides thetaiotaomicron, Bacteroides caccae and Bacteroides fragilis, are predominant members of the human GI microbiota (Eckburg et al., 2005). At the time of writing, the genus Bacteroides comprised more than 37 recognized species (List of Prokaryotic names with Standing in Nomenclature; http://www.bacterio.cict.fr).

Abbreviations: FAMEs, fatty acid methyl esters; Gl, gastrointestinal; ML, maximum-likelihood; MP, maximum-parsimony.

The GenBank/EMBL/DDBJ accession numbers for the 16S rRNA gene sequences of strains YIT $12056^{\top}$, YIT $12057^{\top}$ and YIT $12058^{\top}$ are AB490801, AB490802 and AB490803, respectively.
Although the use of culture-independent molecular techniques to analyse the GI microbiota has allowed more complete and accurate assessment of the biodiversity in this ecosystem, the application of molecular techniques can only examine the function or ecological role of specific micro-organisms indirectly. Therefore, a comprehensive understanding of the physiology of the GI microbiota requires their cultivation. For example, Hooper et al. (2001) revealed that $B$. thetaiotaomicron, one of the culturable and common members of the adult mouse and human GI tract microbiota, modulates expression of host genes that participate in diverse and fundamental physiological functions, indicating that host physiology is influenced by the indigenous microbiota. In view of this finding, we have attempted to facilitate the isolation of as yet uncultured bacteria from the human GI tract (Sakon et al., 2008; Morotomi et al., 2008, 2009, 2010; Nagai et al., $2009,2010)$. In this paper, we report the isolation of three novel species of the genus Bacteroides. Although novel taxonomic units (species) based on a single faecal isolate of a Japanese healthy adult are proposed, each isolate displayed $>98.7 \% 16 \mathrm{~S}$ rRNA gene sequence similarity to some of the human and rat faecal uncultured clones 
reported by several groups, indicating that these bacteria are common members of the intestinal microbiota of man and some other mammals.

Faecal samples were collected from three healthy Japanese males (subjects $\mathrm{H}, \mathrm{S}$ and $\mathrm{O}, 57,37$ and 40 years old, respectively) and immediately transferred into an anaerobic glove box (Coy Laboratory Products, Inc.) which contained $88 \% \mathrm{~N}_{2}, 7 \% \mathrm{H}_{2}$ and $5 \% \mathrm{CO}_{2}$. Each sample was weighed and diluted with pre-reduced $0.1 \mathrm{M}$ PBS $(0.145 \mathrm{M}$ $\mathrm{NaCl}, 0.15 \mathrm{M}$ sodium phosphate; $\mathrm{pH} 7$ ) and spread on modified Gifu anaerobic medium (GAM; Nissui Pharmaceutical) agar plates supplemented with BactoOxgall (Difco), $\mathrm{NaCl}$ or antibiotics to isolate subdominant groups of intestinal microbiota. The composition of the modified GAM agar has been described in a previous report (Sakon et al., 2008). Plates were incubated at $37{ }^{\circ} \mathrm{C}$ for 3 days in an anaerobic glove box as described above. Strain YIT $12056^{\mathrm{T}}$ was isolated from a modified GAM agar plate supplemented with $4 \%$ Bacto-Oxgall and inoculated with a $10^{-5}$ serially diluted faecal sample from subject $\mathrm{H}$. Strain YIT $12057^{\mathrm{T}}$ was isolated from a modified GAM agar plate supplemented with $2 \%$ Bacto-Oxgall and inoculated with a $10^{-5}$ serially diluted faecal sample from subject $S$. Strain YIT $12058^{\mathrm{T}}$ was isolated from a modified GAM agar plate supplemented with $15.6 \mu \mathrm{g}$ oleandomycin $\mathrm{ml}^{-1}$ (Sigma) and inoculated with a $10^{-6}$ serially diluted faecal sample from subject O. Single colonies were picked and grown on modified GAM agar plates. This step was repeated until pure cultures were obtained.

The end products of bacterial metabolism in pre-reduced peptone-yeast extract (PY) medium and PY medium supplemented with glucose (PYG medium) (Holdeman et al., 1977) were analysed by HPLC according to a previously reported procedure (Chonan et al., 1995). Growth was tested in anaerobic and microaerophilic atmospheres which were created by using Anaeropack (Mitsubishi Gas Chemical) and CampyPak Plus microaerophilic system envelopes with palladium catalyst (BBL), respectively. Cellular morphology was observed after Gram-staining of 3 -day plate cultures. Cell dimensions were determined by phase contrast microscopy (BX-50; Olympus) using an ocular micrometer $(\times 10)$ and an objective $(\times 100 / 1.25$ numerical aperture) lens with 3-day plate cultures. Biochemical characteristics were determined using the API Rapid ID 32A and API 20A systems (bioMérieux) according to the manufacturer's instructions and performed in duplicate. Oxidase activity was examined using oxidase test strips (Eiken). The DNA G $+\mathrm{C}$ contents were determined by hydrolysing the DNA enzymically and quantifying the nucleosides by HPLC according to a previously described method (Ezaki et al., 1990). Isoprenoid quinones were extracted as described by Komagata \& Suzuki (1987) and were analysed by an HPLC-atmospheric pressure chemical ionization (APCI)MS/MS system (API3200, Applied Biosystems) using an Lcolumn ODS $(2.1 \times 150 \mathrm{~mm}$, Chemicals Evaluation and Research Institute) by a modified method of Katsuta $e t$ al.
(2005). Cellular fatty acid methyl esters (FAMEs) were obtained from lyophilized cells by saponification, methylation and extraction using minor modifications (Kuykendall et al., 1988) of the method described by Miller (1982). FAMEs were determined by using the MIDI microbial identification system (Microbial ID). DNA extraction, PCR and sequencing of the 16S rRNA genes were performed as described previously (Sakon et al., 2008). Closely related sequences were retrieved from the DNA Data Bank of Japan (DDBJ) using the FASTA program (Pearson \& Lipman, 1985). Sequences were aligned and used to produce the unrooted phylogenetic tree by the neighbour-joining method (Saitou \& Nei, 1987) using CLUSTAL_X software (version 2.0) (Thompson et al., 1997). The topology of the tree was evaluated by a bootstrap analysis with 1000 replicates using CLUSTAL_X. The tree was visualized by the TreeView program (version 1.6.6) (Page, 1996). Maximum-parsimony (MP) and maximum-likelihood (ML) methods were used to confirm the phylogenetic placement of the aligned sequences. MP analysis was performed using the MEGA4 software package (Tamura et al., 2007). The ML tree was calculated with the PhyML program (Guindon \& Gascuel, 2003) using the K2P nucleotide substitution model (Kimura, 1980). The input file was prepared by the SEQBOOT program in the PHYLIP package (Felsenstein, 2005).

Cells of strains YIT $12056^{\mathrm{T}}$, YIT $12057^{\mathrm{T}}$ and YIT $12058^{\mathrm{T}}$ were Gram-stain-negative, non-motile, non-spore-forming and rod-shaped. None of the three strains grew under microaerobic or aerobic conditions. The cell sizes of strain YIT $12056^{\mathrm{T}}$ were $0.5-1.0 \mu \mathrm{m}$ wide and $0.7-2.9 \mu \mathrm{m}$ long. Cells of strain YIT $12057^{\mathrm{T}}$ were usually $1.0-1.4 \mu \mathrm{m}$ wide and 1.0-2.5 $\mu \mathrm{m}$ long and extraordinarily long cells (7.5$52.4 \mu \mathrm{m}$ long) occurred rarely. According to Shah \& Collins (1989), the cell sizes of members of the genus Bacteroides are approximately $0.5-1.3 \mu \mathrm{m}$ wide and $1.6-$ $11 \mu \mathrm{m}$ long, which were consistent with those of these two novel strains. However, the cell size of strain YIT $12058^{\mathrm{T}}$ was 1.0-1.9 $\mu \mathrm{m}$ wide and 1.4-55.0 $\mu \mathrm{m}$ long, indicating that strain YIT $12058^{\mathrm{T}}$ was quite different from other species of the genus Bacteroides due to its large cell size.

Colonies after anaerobic incubation on modified GAM agar plates for 4 days were $1-2 \mathrm{~mm}$ in diameter, translucent whitish, butyrous, entire, circular, convex, shiny, slightly opaque and similar to a pearl in appearance (strain YIT $12056^{\mathrm{T}}$ ); $1-2.5 \mathrm{~mm}$ in diameter, grey-white, butyrous, entire, circular, convex, shiny and opaque (strain YIT $12057^{\mathrm{T}}$ ); and $0.1-3 \mathrm{~mm}$ in diameter, grey-white, butyrous, entire, circular, convex, shiny and opaque (strain YIT $12058^{\mathrm{T}}$ ). Growth of strain YIT $12057^{\mathrm{T}}$ persisted only for a short period, approximately 1-2 days, on modified GAM agar plates at $37^{\circ} \mathrm{C}$.

The major metabolic end products of strain YIT $12056^{\mathrm{T}}$ from glucose in PYG broth were lactic, acetic and succinic acids (9.3, 2.2 and $1.9 \mathrm{mM}$, respectively) and minor amounts of formic and propionic acids were also 
produced. Those of strain YIT $12057^{\mathrm{T}}$ were succinic and acetic acids (19.2 and $12.8 \mathrm{mM}$, respectively) and minor amounts of formic and propionic acids were also produced. The major metabolic end products of strain YIT $12058^{\mathrm{T}}$ were acetic, succinic, formic and lactic acids $(9.8,8.3,3.3$ and $1.7 \mathrm{mM}$, respectively). The results of the phenotypic analyses of the novel strains using the API systems are summarized in Table 1. Although many of the characteristics of the novel isolates were similar to those of related species of the genus Bacteroides, some differences were found.

The major cellular fatty acids of strain YIT $12056^{\mathrm{T}}$ were anteiso- $\mathrm{C}_{15: 0}(26.0 \%)$, iso- $\mathrm{C}_{15: 0}(25.6 \%)$ and summed feature 11 (comprising iso- $\mathrm{C}_{17: 0} 3-\mathrm{OH}$ and/or $\mathrm{C}_{18: 2}$ dimethylacetal; $20.3 \%$ ). Those of strain YIT $12057^{\mathrm{T}}$ were anteiso- $\mathrm{C}_{15: 0}(28.8 \%)$, summed feature $11 \quad(27.8 \%)$, $\mathrm{C}_{18: 1} \omega 9 c(14.0 \%)$ and iso- $\mathrm{C}_{15: 0}(9.3 \%)$. Those of strain YIT $12058^{\mathrm{T}}$ were anteiso-C $\mathrm{C}_{15: 0} \quad(26.1 \%), \mathrm{C}_{18: 1} \omega 9 \mathrm{c}$ $(24.5 \%)$, iso- $\mathrm{C}_{15: 0}(11.7 \%)$ and summed feature 11 $(10.3 \%)$. These results indicate that the major cellular fatty acid compositions of these strains were basically consistent with those of the members of the genus Bacteroides, which contain major amounts of anteisoand iso-methyl branched chain acids (Shah \& Collins, 1983).

The major quinones of members of the genus Bacteroides are menaquinones MK-10 and MK-11 (Shah, 1992). The major quinones of strains YIT $12056^{\mathrm{T}}$ and YIT $12057^{\mathrm{T}}$ were MK-10 (53 and 81\%, respectively) and MK-11 (47 and $19 \%$, respectively). Strain YIT $12058^{\mathrm{T}}$ also had a trace

Table 1. Phenotypic characteristics of strains YIT $12056^{\top}$, YIT $12057^{\top}$, YIT $12058^{\top}$ and phylogenetically related members of the genus Bacteroides

Taxa: 1, YIT $12056^{\mathrm{T}}$; 2, YIT $12057^{\mathrm{T}}$; 3, YIT $12058^{\mathrm{T}}$; 4, B. uniformis JCM $5828^{\mathrm{T}}$ (data from Bakir et al., 2006; Lan et al., 2006); 5, B. intestinalis JCM $13265^{\mathrm{T}}$ (Bakir et al., 2006); 6, B. gallinarum JCM $13658^{\mathrm{T}}$ (Lan et al., 2006). Data for strains YIT $12056^{\mathrm{T}}$, YIT $12057^{\mathrm{T}}$ and YIT $12058^{\mathrm{T}}$ are from this study. All strains were positive for hydrolysis of aesculin, indole production, acid production from cellobiose, lactose, maltose, D-mannose, raffinose, sucrose and D-xylose. All strains were also positive for alanine arylamidase, alkaline phosphatase, $\beta$-galactosidase, $\alpha$-glucosidase, $\beta$ glucosidase and leucyl glycine arylamidase. All strains were negative for nitrate reduction, urease, arginine dihydrolase and histidine-, leucine-, phenylalanine-, proline-, pyroglutamic acid- and serine arylamidase. +, Positive; -, negative; w, weakly positive; v, variable; ND, no data available.

\begin{tabular}{|c|c|c|c|c|c|c|}
\hline Characteristic & 1 & 2 & 3 & 4 & 5 & 6 \\
\hline Isolation source & Human faeces & Human faeces & Human faeces & Human faeces & Human faeces & Chicken caecum \\
\hline Catalase & - & - & + & - & $\mathrm{ND}$ & - \\
\hline Gelatin hydrolysis & - & - & + & - & - & - \\
\hline \multicolumn{7}{|l|}{ Acid production from: } \\
\hline L-Arabinose & - & + & + & + & + & + \\
\hline Glycerol & $\mathrm{W}$ & + & + & - & - & - \\
\hline D-Mannitol & $\mathrm{w}$ & + & + & - & - & - \\
\hline L-Rhamnose & + & + & + & - & + & $\mathrm{W}$ \\
\hline Salicin & $\mathrm{W}$ & + & + & + & - & - \\
\hline D-Sorbitol & $\mathrm{W}$ & + & + & - & - & - \\
\hline Trehalose & $\mathrm{W}$ & + & + & - & - & - \\
\hline \multicolumn{7}{|l|}{ Enzyme activities: } \\
\hline$N$-Acetyl- $\beta$-glucosaminidase & $\mathrm{W}$ & + & + & + & + & + \\
\hline$\alpha$-Arabinosidase & - & - & + & + & + & + \\
\hline Arginine arylamidase & - & $\mathrm{w}$ & - & - & - & - \\
\hline$\alpha$-Fucosidase & - & + & - & + & + & - \\
\hline$\alpha$-Galactosidase & + & + & + & + & + & - \\
\hline 6-Phospho- $\beta$-galactosidase & - & - & - & $\mathrm{V}$ & - & - \\
\hline$\beta$-Glucuronidase & - & + & - & - & - & - \\
\hline Glutamic acid decarboxylase & + & - & + & + & + & + \\
\hline Glutamyl glutamic acid arylamidase & + & + & - & + & + & + \\
\hline Glycine arylamidase & - & $\mathrm{w}$ & - & - & - & - \\
\hline Valine arylamidase & - & - & $\mathrm{w}$ & - & - & - \\
\hline DNA G $+\mathrm{C}$ content $(\mathrm{mol} \%)$ & 45.3 & 45.2 & 43.6 & $46.1-47.8$ & 44 & 47 \\
\hline Distinctive major cellular fatty acids* & $\begin{array}{l}\text { iso- } \mathrm{C}_{15: 0} \\
\text { summed } \\
\text { feature } 11\end{array}$ & $\begin{array}{c}\mathrm{C}_{18: 1} \omega 9 c \\
\text { summed feature } \\
11, \text { iso- } \mathrm{C}_{15: 0}\end{array}$ & $\begin{array}{l}\mathrm{C}_{18: 1} \omega 9 c \text {, iso- } \\
\mathrm{C}_{15: 0}, \text { summed } \\
\quad \text { feature } 11\end{array}$ & $\begin{array}{c}\text { iso- } \mathrm{C}_{17: 0} 3-\mathrm{OH}, \\
\quad \text { iso- } \mathrm{C}_{15: 0}\end{array}$ & $\begin{array}{c}\text { iso- } \mathrm{C}_{17: 0} \\
3-\mathrm{OH}\end{array}$ & $\begin{array}{c}\text { iso- } \mathrm{C}_{17: 0} 3-\mathrm{OH}, \\
\text { iso- } \mathrm{C}_{15: 0}\end{array}$ \\
\hline
\end{tabular}

${ }^{*}$ Anteiso- $\mathrm{C}_{15: 0}$ is major component in all strains. Summed features represent group of two or three fatty acids that could not be separated using GC with the MIDI system. Summed feature 11 contains iso- $\mathrm{C}_{17: 0} 3-\mathrm{OH}$ and/or $\mathrm{C}_{18: 2}$ dimethylacetal. 
amount of MK-10 and MK-11, with no other quinones detected. The DNA G + C contents of strains YIT $12056^{\mathrm{T}}$, YIT $12057^{\mathrm{T}}$ and YIT $12058^{\mathrm{T}}$ were $45.3,45.2$ and $43.6 \mathrm{~mol} \%$, respectively, which supported their affiliation to the genus Bacteroides, members of which have DNA $\mathrm{G}+\mathrm{C}$ contents of between 40 and $48 \mathrm{~mol} \%$ (Shah, 1992)

Almost complete $16 \mathrm{~S}$ rRNA gene sequences of strains YIT $12056^{\mathrm{T}}$ (1481 bp), YIT $12057^{\mathrm{T}}$ (1477 bp) and YIT $12058^{\mathrm{T}}$ (1476 bp) were determined. Database searches revealed that the most similar sequences to those of the novel isolates were Bacteroides gallinarum JCM $13658^{\mathrm{T}}$ with approximately $96.6 \%$ similarity (YIT $12056^{\mathrm{T}}$ ), Bacteroides uniformis JCM $5828^{\mathrm{T}}$ with approximately $95.0 \%$ similarity (YIT $12057^{\mathrm{T}}$ ) and Bacteroides intestinalis JCM $13265^{\mathrm{T}}$ with approximately $96.7 \%$ similarity (YIT $12058^{\mathrm{T}}$ ). The $16 \mathrm{~S}$ rRNA gene sequences of strains YIT $12056^{\mathrm{T}}$, YIT $12057^{\mathrm{T}}$, YIT $12058^{\mathrm{T}}$ and related type species of the genus Bacteroides were aligned and a phylogenetic tree was constructed using Escherichia coli as an outgroup, with closely related uncultured clones obtained from human faeces described below (Fig. 1). The phylogenetic tree showed that all three new isolates belonged to the genus Bacteroides. The position of each strain was phylogenetically distinct and their specific lineages were robust, supported by high bootstrap values. These results were congruent with those obtained using the MP and ML methods (data not shown).

The database searches also revealed that several uncultured clones displayed $>98.7 \%$ sequence similarity to strains YIT
$12056^{\mathrm{T}}$, YIT $12057^{\mathrm{T}}$ and YIT $12058^{\mathrm{T}}$. For example, strain YIT $12056^{\mathrm{T}}$ was related to the faecal uncultured clones from human subjects reported by Li et al. (2008) (GenBank accession no. EF405059) and Suau et al. (1999) (AF132259). Strain YIT $12057^{\mathrm{T}}$ was also related to the human faecal uncultured clones reported by Ley et al. (2006) (DQ793778 and another 9 clones). Strain YIT $12058^{\mathrm{T}}$ was related to the faecal uncultured clones from humans (Dethlefsen et al., 2008; EU763372 and 4 other clones) and rats (S. P. J. Brooks and others, unpublished, FJ880188 and 3 other clones). These data indicated that these three novel strains occur in faeces of human and some other mammals as common members of the intestinal microbiota. It is evident from the results of the taxonomic study that the Gram-negative-staining strains YIT $12056^{\mathrm{T}}$, YIT $12057^{\mathrm{T}}$ and YIT $12058^{\mathrm{T}}$ recovered from human faeces represent hitherto unknown species of the genus Bacteroides. On the basis of phylogenetic and phenotypic analyses, we propose that these strains represent three novel species of the genus Bacteroides: Bacteroides clarus sp. nov., Bacteroides fluxus sp. nov. and Bacteroides oleiciplenus sp. nov. Differential characteristics of the novel species and related species of the genus Bacteroides are shown in Table 1.

\section{Description of Bacteroides clarus sp. nov.}

Bacteroides clarus (cla'rus. L. masc. adj. clarus shining, referring to the shiny appearance of the colonies).

Cells are obligately anaerobic, Gram-stain-negative, nonmotile, non-spore-forming, rod-shaped and approximately

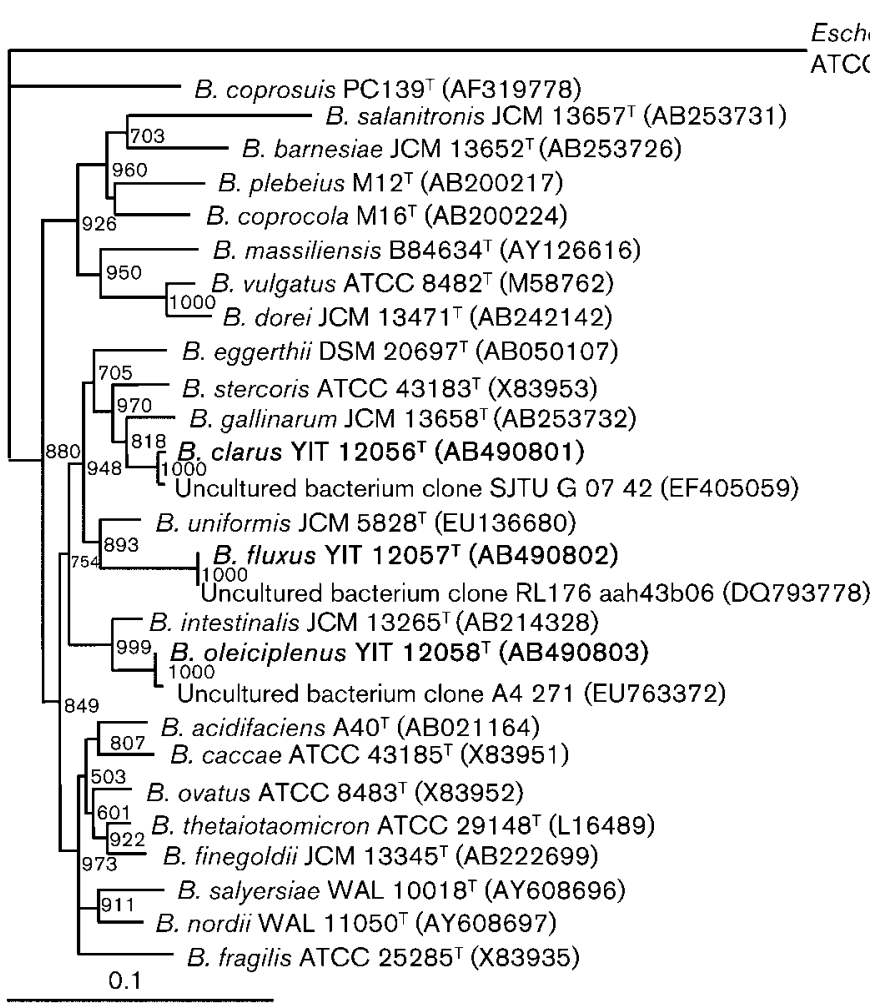

Fig. 1. Phylogenetic tree showing the positions of Bacteroides clarus sp. nov. YIT $12056^{\top}$, Bacteroides fluxus sp. nov. YIT $12057^{\top}$, Bacteroides oleiciplenus sp. nov. YIT $12058^{\top}$, other members of the genus Bacteroides and selected uncultured bacterial clones based on 16S rRNA gene sequence similarity data. The tree was rooted with Escherichia coli ATCC $11775^{\top}$ and constructed by using the neighbour-joining method; bootstrap values from 1000 replications are given at the nodes. GenBank/EMBL/ DDBJ accession numbers are shown in parentheses. Bar, 0.1 substitutions per nucleotide position. 
0.5-1.0 $\mu \mathrm{m}$ wide and $0.7-2.9 \mu \mathrm{m}$ long. Colonies on modified GAM agar plates after 4 days anaerobic incubation are $1-2 \mathrm{~mm}$ in diameter, translucent whitish, butyrous, entire, circular, convex, shiny and slightly opaque. Major end products of glucose metabolism in PYG broth are lactic, acetic and succinic acids. The major cellular fatty acids are anteiso- $\mathrm{C}_{15: 0}$, iso- $\mathrm{C}_{15: 0}$ and summed feature 11 (comprising iso- $\mathrm{C}_{17: 0} 3-\mathrm{OH}$ and/or $\mathrm{C}_{18: 2}$ dimethylacetal). The main respiratory quinones are MK-10 and MK-11. The phenotypic characteristics of the type strain obtained with API systems are shown in Table 1.

The type strain, YIT $12056^{\mathrm{T}} \quad\left(=\mathrm{JCM} \quad 16067^{\mathrm{T}}=\mathrm{DSM}\right.$ $22519^{\mathrm{T}}$ ), was isolated from human faeces. The DNA $\mathrm{G}+\mathrm{C}$ content of the type strain is $45.3 \mathrm{~mol} \%$.

\section{Description of Bacteroides fluxus sp. nov.}

Bacteroides fluxus (flu'xus. L. masc. adj. fluxus transient or perishable, referring to the short-lived nature of this bacterium during cultivation).

Cells are obligately anaerobic, Gram-stain-negative, nonmotile, non-spore-forming, rod-shaped and usually 1.0$1.4 \mu \mathrm{m}$ wide and 1.0-2.5 $\mu \mathrm{m}$ long. Extraordinarily long cells $(7.5-52.4 \mu \mathrm{m}$ long) occur rarely. Colonies on modified GAM agar plates after 4 days anaerobic incubation are $1-2.5 \mathrm{~mm}$ in diameter, grey-white, butyrous, entire, circular, convex, shiny and opaque. Major end products of glucose metabolism in PYG broth are succinic and acetic acids. The major cellular fatty acids are anteiso$\mathrm{C}_{15: 0}$, summed feature 11 (comprising iso- $\mathrm{C}_{17: 0} 3-\mathrm{OH}$ and/or $\mathrm{C}_{18: 2}$ dimethylacetal), $\mathrm{C}_{18: 1} \omega 9 \mathrm{c}$ and iso- $\mathrm{C}_{15: 0}$. The main respiratory quinones are MK-10 and MK-11. The phenotypic characteristics of the type strain obtained with API systems are shown in Table 1.

The type strain, YIT $12057^{\mathrm{T}} \quad\left(=\mathrm{JCM} \quad 16101^{\mathrm{T}}=\mathrm{DSM}\right.$ $\left.22534^{\mathrm{T}}\right)$, was isolated from human faeces. The DNA $\mathrm{G}+\mathrm{C}$ content of the type strain is $45.2 \mathrm{~mol} \%$.

\section{Description of Bacteroides oleiciplenus sp. nov.}

Bacteroides oleiciplenus (o.le.i.ci.ple' nus. N.L. n. acidum oleicum oleic acid; L. adj. plenus full of, abounding in; N.L. masc. adj. oleiciplenus abounding in oleic acid, referring to the cellular fatty acid composition).

Cells are obligately anaerobic, Gram-stain-negative, nonmotile, non-spore-forming, rod-shaped and approximately $1.0-1.9 \mu \mathrm{m}$ wide and $1.4-55.0 \mu \mathrm{m}$ long. Colonies on modified GAM agar plates after 4 days anaerobic incubation are $0.1-3 \mathrm{~mm}$ in diameter, grey-white, butyrous, entire, circular, convex, shiny and opaque. Major end products of glucose metabolism in PYG broth are acetic, succinic, formic and lactic acids. The major cellular fatty acids are anteiso$\mathrm{C}_{15: 0}, \mathrm{C}_{18: 1} \omega 9 c$, iso- $\mathrm{C}_{15: 0}$, and summed feature 11 (comprising iso- $\mathrm{C}_{17: 0} 3-\mathrm{OH}$ and/or $\mathrm{C}_{18: 2}$ dimethylacetal). The main respiratory quinones are MK-10 and MK-11.
Phenotypic characteristics of the type strain obtained with the API systems are shown in Table 1.

The type strain, YIT $12058^{\mathrm{T}} \quad\left(=\mathrm{JCM} \quad 16102^{\mathrm{T}}=\mathrm{DSM}\right.$ $\left.22535^{\mathrm{T}}\right)$, was isolated from human faeces. The DNA $\mathrm{G}+\mathrm{C}$ content of the type strain is $43.6 \mathrm{~mol} \%$.

\section{Acknowledgements}

We are grateful to Professor Jean P. Euzéby of the École Nationale Vétérinaire in Toulouse for his suggestions regarding the etymology of the species epithets. We thank T. Takada, K. Manabe and K. Minowa for advice and help in the phenotypic analyses. We also thank Dr H. Sawada for his understanding and encouragement through our research activities.

\section{References}

Bakir, M. A., Kitahara, M., Sakamoto, M., Matsumoto, M. \& Benno, Y. (2006). Bacteroides intestinalis sp. nov., isolated from human faeces. Int J Syst Evol Microbiol 56, 151-154.

Chonan, O., Matsumoto, K. \& Watanuki, M. (1995). Effect of galactooligosaccharides on calcium absorption and preventing bone loss in ovariectomized rats. Biosci Biotechnol Biochem 59, 236-239.

Dethlefsen, L., Huse, S., Sogin, M. L. \& Relman, D. A. (2008). The pervasive effects of an antibiotic on the human gut microbiota, as revealed by deep 16S rRNA sequencing. PLoS Biol 6, e280.

Eckburg, P. B., Bik, E. M., Bernstein, C. N., Purdom, E., Dethlefsen, L., Sargent, M., Gill, S. R., Nelson, K. E. \& Relman, D. A. (2005). Diversity of the human intestinal microbial flora. Science 308, 16351638.

Ezaki, T., Saidi, S. M., Liu, S.-L., Hashimoto, Y., Yamamoto, H. \& Yabuuchi, E. (1990). Rapid procedure to determine the DNA base composition from small amounts of Gram-positive bacteria. FEMS Microbiol Lett 67, 127-130.

Felsenstein, J. (2005). PHYLIP (phylogeny inference package), version 3.6. Distributed by the author. Department of Genome Sciences, University of Washington, Seattle, USA.

Guindon, S. \& Gascuel, O. (2003). A simple, fast, and accurate algorithm to estimate large phylogenies by maximum likelihood. Syst Biol 52, 696-704.

Hayashi, H., Sakamoto, M. \& Benno, Y. (2002). Phylogenetic analysis of the human gut microbiota using 16S rDNA clone libraries and strictly anaerobic culture-based methods. Microbiol Immunol 46, 535548.

Holdeman, L. V., Cato, E. P. \& Moore, W. E. C. (1977). Anaerobe Laboratory Manual, 4th edn. Blacksburg, VA: Virginia Polytechnic Institute and State University.

Hooper, L. V., Wong, M. H., Thelin, A., Hansson, L., Falk, P. G. \& Gordon, J. I. (2001). Molecular analysis of commensal host-microbial relationships in the intestine. Science 291, 881-884.

Katsuta, A., Adachi, K., Matsuda, S., Shizuri, Y. \& Kasai, K. (2005). Ferrimonas marina sp. nov. Int J Syst Evol Microbiol 55, 1851-1855.

Kimura, M. (1980). A simple method for estimating evolutionary rates of base substitutions through comparative studies of nucleotide sequences. J Mol Evol 16, 111-120.

Komagata, K. \& Suzuki, K. (1987). Lipid and cell-wall analysis in bacterial systematics. Methods Microbiol 19, 161-207.

Kurokawa, K., Itoh, T., Kuwahara, T., Oshima, K., Toh, H., Toyoda, A., Takami, H., Morita, H., Sharma, V. K. \& other authors (2007). 
Comparative metagenomics revealed commonly enriched gene sets in human gut microbiomes. DNA Res 14, 169-181.

Kuykendall, L. D., Roy, M. A., O'Neill, J. J. \& Devine, T. E. (1988). Fatty acids, antibiotic resistance, and deoxyribonucleic acid homology groups of Bradyrhizobium japonicum. Int J Syst Bacteriol 38, 358-361.

Lan, P. T., Sakamoto, M., Sakata, S. \& Benno, Y. (2006). Bacteroides barnesiae sp. nov., Bacteroides salanitronis sp. nov. and Bacteroides gallinarum sp. nov., isolated from chicken caecum. Int J Syst Evol Microbiol 56, 2853-2859.

Ley, R. E., Turnbaugh, P. J., Klein, S. \& Gordon, J. I. (2006). Microbial ecology: human gut microbes associated with obesity. Nature 444, 1022-1023.

Li, M., Wang, B., Zhang, M., Rantalainen, M., Wang, S., Zhou, H., Zhang, Y., Shen, J., Pang, X. \& other authors (2008). Symbiotic gut microbes modulate human metabolic phenotypes. Proc Natl Acad Sci U S A 105, 2117-2122.

Miller, L. T. (1982). Single derivatization method for routine analysis of bacterial whole-cell fatty acid methyl esters, including hydroxy acids. J Clin Microbiol 16, 584-586.

Morotomi, M., Nagai, F., Sakon, H. \& Tanaka, R. (2008). Dialister succinatiphilus sp. nov. and Barnesiella intestinihominis sp. nov., isolated from human faeces. Int J Syst Evol Microbiol 58, 2716-2720.

Morotomi, M., Nagai, F., Sakon, H. \& Tanaka, R. (2009). Paraprevotella clara gen. nov., sp. nov., and Paraprevotella xylaniphila sp. nov., new members of the family Prevotellaceae isolated from human faeces. Int J Syst Evol Microbiol 59, 1895-1900.

Morotomi, M., Nagai, F., Sakon, H. \& Tanaka, R. (2010). Succinatimonas hippei gen. nov., sp. nov., isolated from human faeces. Int J Syst Evol Microbiol 60, 1788-1793.

Nagai, F., Morotomi, M., Sakon, H. \& Tanaka, R. (2009). Parasutterella excrementihominis gen. nov., sp. nov., a novel member of the family Alcaligenaceae, isolated from human faeces. Int J Syst Evol Microbiol 59, 1793-1797.

Nagai, F., Morotomi, M., Watanabe, Y., Sakon, H. \& Tanaka, R. (2010). Alistipes indistinctus sp. nov. and Odoribacter laneus sp. nov., common members of the human intestinal microbiota isolated from faeces. Int J Syst Evol Microbiol 60, 1296-1302.

Page, R. D. M. (1996). TreeView: an application to display phylogenetic trees on personal computers. Comput Appl Biosci 12, 357-358.

Pearson, W. R. \& Lipman, D. J. (1985). Rapid and sensitive protein similarity searches. Science 227, 1435-1441.

Saitou, N. \& Nei, M. (1987). The neighbor-joining method: a new method for reconstructing phylogenetic trees. Mol Biol Evol 4, 406-425.

Sakon, H., Nagai, F., Morotomi, M. \& Tanaka, R. (2008). Sutterella parvirubra sp. nov. and Megamonas funiformis sp. nov., isolated from human faeces. Int J Syst Evol Microbiol 58, 970-975.

Shah, H. N. (1992). The genus Bacteroides and related taxa. In The Prokaryotes, 2nd edn, pp. 3593-3607. Edited by A. Balows, H. G. Trüper, M. Dworkin, W. Harder \& K. H. Schleifer. New York: Springer.

Shah, H. N. \& Collins, M. D. (1983). Genus Bacteroides. A chemotaxonomical perspective. J Appl Bacteriol 55, 403-416.

Shah, H. N. \& Collins, M. D. (1989). Proposal to restrict the genus Bacteroides (Castellani and Chalmers) to Bacteroides fragilis and closely related species. Int J Syst Bacteriol 39, 85-87.

Suau, A., Bonnet, R., Sutren, M., Godon, J. J., Gibson, G. R., Collins, M. D. \& Doré, J. (1999). Direct analysis of genes encoding $16 \mathrm{~S}$ rRNA from complex communities reveals many novel molecular species within the human gut. Appl Environ Microbiol 65, 4799-4807.

Tamura, K., Dudley, J., Nei, M. \& Kumar, S. (2007). MEgA4: Molecular evolutionary genetics analysis (MEGA) software version 4.0. Mol Biol Evol 24, 1596-1599.

Thompson, J. D., Gibson, T. J., Plewniak, F., Jeanmougin, F. \& Higgins, D. G. (1997). The CLUSTAL_X windows interface: flexible strategies for multiple sequence alignment aided by quality analysis tools. Nucleic Acids Res 25, 4876-4882.

Wang, X., Heazlewood, S. P., Krause, D. O. \& Florin, T. H. (2003). Molecular characterization of the microbial species that colonize human ileal and colonic mucosa by using $16 \mathrm{~S}$ rDNA sequence analysis. J Appl Microbiol 95, 508-520. 